\title{
CORRIGENDUM
}

\section{Flt-3 internal tandem duplication hampers differentiation of AML blasts towards leukemic dendritic cells}

I Houtenbos, TM Westers, GJ Ossenkoppele, AA van de Loosdrecht, CJ Hess and Q Waisfisz

Leukemia (2006) 20, 2219. doi:10.1038/sj.leu.2404427

Correction to: Leukemia 2006; 20: 1892-1895.

doi:10.1038/sj.leu.2404348

It has been identified by the authors that there has been an error

in the sequence of author names.

The correct sequence is as follows:
I Houtenbos, TM Westers, CJ Hess, Q Waisfisz, GJ Ossenkoppele and AA van de Loosdrecht.

The authors apologize for any inconvenience caused. 